\title{
Genomic structure of carp mitogen-activated protein kinase kinase 1 gene
}

\author{
Jiann-Horng Leu ${ }^{a}$, Ming-Shyue Lee ${ }^{b}$, Kuan-Tien Chen ${ }^{c}$, Geen-Dong Chang ${ }^{b}$, \\ Chen-Kung Chou ${ }^{d}$, Chang-Jen Huang ${ }^{\text {a, * }}$ \\ ${ }^{a}$ Institute of Biological Chemistry, Academia Sinica, Taipei, Taiwan \\ ${ }^{b}$ Graduate Institute of Biochemical Sciences, and National Taiwan University, Taipei, Taiwan \\ ${ }^{c}$ Department of Surgery, University Hospital, National Taiwan University, Taipei, Taiwan \\ d Department of Medical Research, Veterans General Hospital, Taipei, Taiwan
}

Received 30 November 1995; accepted 16 January 1996

\begin{abstract}
Carp mitogen-activated protein kinase kinase $1(c M K K 1)$ gene was isolated from a liver genomic library. The sequence around the exon-intron boundaries and $2 \mathrm{~kb}$ of the promoter region were determined. Our data indicate that this gene is composed of 11 exons and 10 introns spanning about $9 \mathrm{~kb}$. Multiple potential transcription initiation sites were located by primer extension analysis. Examination of 2 $\mathrm{kb}$ of $5^{\prime}$-flanking sequence revealed potential binding sites for a variety of transcription factors such as E2F, Ets-1, GATA-1, Myb, NF-IL6, Sp1, and NF-kB.
\end{abstract}

Keywords: Genomic DNA sequence; Mitogen-activated protein kinase kinase; (Cyprinus carpio)

Mitogen-activated protein (MAP) kinases, also known as extracellular signal-regulated kinases (ERKs), are a family of serine/threonine kinases that mediate intracellular protein phosphorylation events. They have been shown to participate in a variety of signal transduction pathways and are rapidly activated in response to various extracellular stimuli [1-4]. Several subgroups of MAP kinase have been identified in vertebrates including the ERK1 and ERK2 [5,6], c-jun amino-terminal kinase (JNK) [7,8], p38 [9-11], and ERK5 [12].

The activation of MAP kinase is triggered by an upstream activator, called MAP kinase kinase (MKK) or MAPK/ERK kinase (MIEK) [13]. MEK is a dual specificity kinase that phosphorylates MAP kinase on both tyrosine and threonine residues $[14,15]$, whereas it is activated and phosphorylated by a further upstream activator on its serine/threonine residues [16]. Recently, there are also a growing number of MEKs $[12,17,18]$. Specific MEKs have been shown to phosphorylate specific MAP kinases in a given pathway. For example, MEK1 and MEK2 phosphorylate ERK1 and ERK2 in the cellular

\footnotetext{
${ }^{*}$ Corresponding author. Fax: +88623635038.
}

processes such as proliferation, differentiation, and development $[4,13]$. MEK3 and $\mathrm{p} 38$ are involved in the cytokine response $[18,19]$, whereas MEK4 and JNK are shown to participate in the stress response [18]. More recently, MEK5 and ERK5 have been identified to constitute a new signal transduction pathway [12].

As an initial step to study signal transduction in fish, we have cloned a full-length cDNA encoding the carp MAP kinase kinase 1 (cMKK1) [20]. In this study, we further determined the genomic structure and the promoter region of this gene.

A commercially available carp liver lambda FIX II genomic library (Stratagene, La Jolla, CA, USA) was screened using the carp cDNA coding for MKK1 [20] as a probe. The probe was labeled using a DIG DNA Labeling Kit (Boehringer Mannheim, Mannheim, Germany). Two genomic clones (M1 and M2) were isolated from the library. As shown in Fig. 1, the carp $M K K 1$ gene spanned about $9 \mathrm{~kb}$ and was composed of 11 exons and 10 introns. The sequence around the exon-intron boundaries was determined and shown in Table 1. All exon/intron boundaries identified conformed to the GT/AG splice donor/acceptor rule [23]. Some exons were relatively small ( $46 \mathrm{bp}$ to $78 \mathrm{bp}$ ), whereas the first and the last exons 


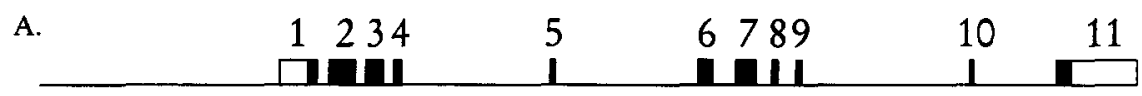

B.

HEP $\quad$ PBXh $\quad S \quad P \quad$ P

C.

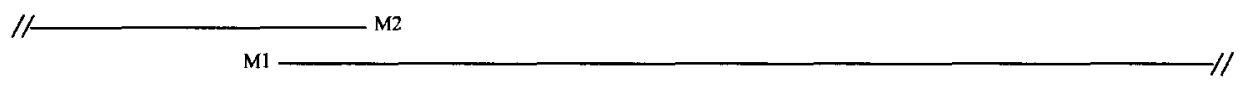

\begin{tabular}{lllllllllll}
0 & 1 & 2 & 3 & 4 & 5 & 6 & 7 & 8 & 9 \\
\hline
\end{tabular}

Fig. 1. Physical map of the carp $M K K l$ gene. (A) The structure of the gene is represented with regard to the organization of the exons and introns. Exons are indicated to scale by boxes 1-11. Solid boxes indicate the carp MKK1 coding region, whereas open boxes represent the $5^{\prime}$ - and $3^{\prime}$-untranslated region. Introns and the $5^{\prime}$ - and $3^{\prime}$-flanking regions regions are indicated by the solid lines. The entire gene spans about $9 \mathrm{~kb}$ in length and contains 11 exons. (B) The restriction map shows cleavage sites for endonucleases $B g l \mathrm{II}(\mathrm{B}), E c o \mathrm{RI}(\mathrm{E}), \operatorname{HindIII}(\mathrm{H}), P s t \mathrm{I}(\mathrm{P}), \operatorname{SacI}(\mathrm{S}), X b a \mathrm{I}(\mathrm{X})$, and Xhol (Xh). (C) The two overlapping phage clones, M1, and M2, isolated from a Lambda FIX II carp genomic library, are shown to scale.

were large ( $341 \mathrm{bp}$ and $612 \mathrm{bp}$ ). The size of introns varied considerably, ranging from $83 \mathrm{bp}$ (intron 3) to $1.4 \mathrm{~kb}$ (intron 9). The first exon contained the $5^{\prime}$-untranslated region and the first 28 amino acids and the last exon contained the last 36 amino acids plus the $3^{\prime}$-untranslated region. The other 9 exons (exon 2 to exon 10) encoded the kinase catalytic domain.

To identify sequence elements that might be involved in the transcriptional regulation of the carp $M K K l$ gene, the nucleotide sequence of $2 \mathrm{~kb}$ of the 5 -upstream region of the $M K K 1$ gene relative to the ATG translation start codon was determined and shown in Fig. 2. Computer analysis of the sequence revealed numerous potential binding sites for transcription factors. One TATA box [21] and a CCAAT motif [22] was observed at the position of nucleotides -753 to -748 and -1331 to -1327 , respectively. However, these elements were located too far upstream from the transcription initiation site. Two putative binding sites for E2F [23] were found at the position of nucleotides -607 to -599 and -364 to -356 . Another potential binding site for NF-IL6 [24] was also observed at the position of nucleotides -1444 to -1436 . It has been shown that genes containing the NF-IL6 binding site are induced during inflammation [25]. Two proto-oncogene products Ets [26] and Myb [27] binding sites were also found at the position of nucleotides -1230 to -1225 , and

Table 1

Exon-intron sizes and junction sequences of the carp $M K K I$ gene

\begin{tabular}{|c|c|c|c|c|c|c|}
\hline $\begin{array}{l}\text { Exon } \\
\text { number }\end{array}$ & $\begin{array}{l}\text { Exon size } \\
\text { (bp) }\end{array}$ & $\begin{array}{l}3^{\prime} \text { end of } \\
\text { the exon }\end{array}$ & $\begin{array}{l}5 \text { 'end of } \\
\text { the intron }\end{array}$ & $\begin{array}{l}\text { Approximate } \\
\text { size (bp) }\end{array}$ & $\begin{array}{l}3^{\prime} \text { end of } \\
\text { the intron }\end{array}$ & $\begin{array}{l}5 \text { 'end of } \\
\text { the exon }\end{array}$ \\
\hline 1 & 341 & $\begin{array}{l}\text { GCA GCA TCA GA } \\
\text { A A S E }\end{array}$ & gtacgtatagagtt & 84 & ttccetgtctttag & $\begin{array}{l}\text { G GCC AAC CTG } \\
\text { A N L }\end{array}$ \\
\hline 2 & 211 & $\begin{array}{l}\text { ATG GCC AGG AAG } \\
\text { M A R K }\end{array}$ & gtaagcgatcgacg & 93 & tgtattttccccag & $\begin{array}{l}\text { CTC ATT CAT } \\
\text { L I H }\end{array}$ \\
\hline 3 & 147 & $\begin{array}{l}\text { ATG GAC CAC ATG } \\
\text { M E H M }\end{array}$ & gtggggccagtggt & 83 & tgtatttgtcgcag & $\begin{array}{l}\text { GAT GGA GGC } \\
\text { D G G }\end{array}$ \\
\hline 4 & 78 & $\begin{array}{l}\text { GTT AGC ATA GCT } \\
\text { V S I A }\end{array}$ & gtaagtattatcaa & 1200 & ctctctttccacag & $\begin{array}{l}\text { GTA CTC AGA } \\
\text { V L R }\end{array}$ \\
\hline 5 & 52 & $\begin{array}{l}\text { ATG CAC AGA G } \\
\text { M H R D }\end{array}$ & gtacactcagagca & 1160 & aataatgcacagag & $\begin{array}{l}\text { AC GTT AAG CCC } \\
\text { V K P }\end{array}$ \\
\hline 6 & 125 & $\begin{array}{l}\text { TCG TAC ATG TCG } \\
\text { S Y M S }\end{array}$ & gtgagtcacccacc & 194 & ctctgccttgacag & $\begin{array}{l}\text { CCG GAG AGA } \\
\text { P E R }\end{array}$ \\
\hline 7 & 214 & $\begin{array}{l}\text { CCA GTT AGC G } \\
\text { PV S G }\end{array}$ & gtaagaacttgtta & 120 & ttgttttcceccag & $\begin{array}{l}\text { GA CAC GGA ATG } \\
\text { H G M }\end{array}$ \\
\hline 8 & 65 & $\begin{array}{l}\text { ATT GTC AAT GAG } \\
\text { I V N E }\end{array}$ & gtcagagaatttgc & 131 & tctacatcctgcag & $\begin{array}{l}\text { CCA CCA CCC } \\
\text { P P P }\end{array}$ \\
\hline 9 & 62 & $\begin{array}{l}\text { GTG ATG AAA TG } \\
\text { V M K C }\end{array}$ & gtgagctcctgttt & 1400 & gtgttttttcacag & $\begin{array}{l}\text { C CT ATG AAG } \\
\text { L M K }\end{array}$ \\
\hline 10 & 46 & $\begin{array}{l}\text { AAG ATG CTA ATG } \\
\text { K M L M }\end{array}$ & gtacgtacctttcc & 380 & atgttaatttacag & $\begin{array}{l}\text { GGC CAC ACG } \\
\text { G H T }\end{array}$ \\
\hline 11 & 612 & \multicolumn{5}{|c|}{$\begin{array}{l}\text { AAAATGGATAGCTTGGTTCAAAGGCAAACATTTAATTGAGAATCAACTGGCGTTGCATCAAG } \\
\text { (the end of the CDNA) }\end{array}$} \\
\hline
\end{tabular}


-1289 to -1284 and -1676 to -1671 , respectively. A site for NF-kB [28], a ubiquitous gene activator that is induced in response to various extracellular signals, was observed at the position of nucleotides -1851 to -1842 . NF-kB has been shown to involve the physical interaction of Sp1 [29] which was also found at the position of nucleotides -1276 to -1271 . In addition, a consensus GATA-1 [30] binding sequence was observed at the position of nucleotides -1523 to -1518 .

The transcription initiation site of the carp $M K K I$ gene was determined by primer extension of the $5^{\prime}$ ends of the carp ovary poly $(\mathrm{A})^{+}$RNA. Four major extended products were revealed (Fig. 3). The exact position of the extended products was determined by aligning the sequencing ladder obtained with the same primer. The bands A, B, C, and D

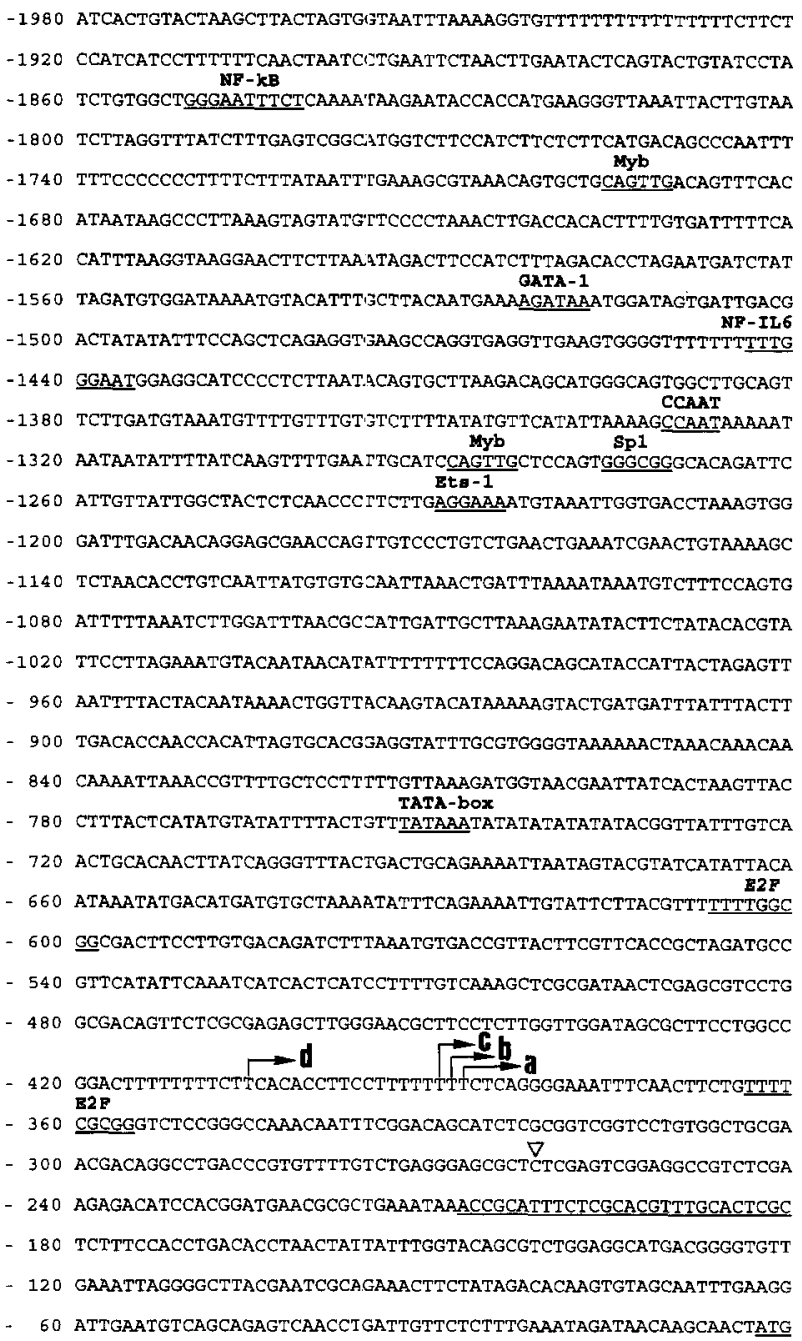

Fig. 2. Nucleotide sequence of the $5^{\prime}$-flanking region of the carp $M K K 1$ gene. The nucleotide number $(-1)$ start at the $G$ of the putative ATG codon [20]. Potential binding sites for a variety of transcription factors are underlined. The 28-mer antisense oligonucleotide used for primer extension analysis is also underlined. Candidate transcription start sites by primer extension (see Fig. 3) are indicated by bent arrows. The start of the carp MKK1 cDNA clone MKK30 [20] is marked by open triangle at position -262

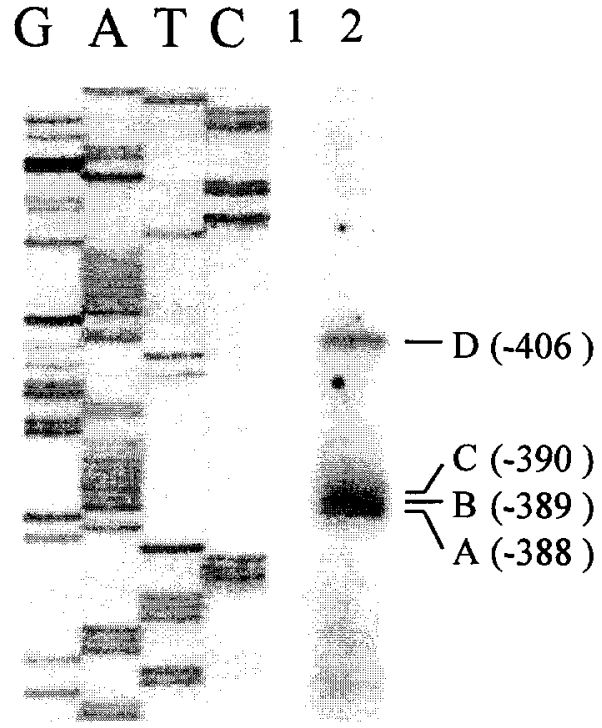

Fig. 3. Determination of the transcription initiation site of the carp $M K K I$ gene. [ ${ }^{32} \mathrm{P}$ ]-labeled primer (see Fig. 2) was annealed to $10 \mu \mathrm{g}$ yeast tRNA (lane 1 , as a negative control) or $5 \mu \mathrm{g}$ poly (A) ${ }^{+}$RNA from carp ovary (lane 2) and extended with reverse transcriptase. The sequencing ladder of the carp $M K K I$ gene labeled $\mathrm{G}, \mathrm{A}, \mathrm{T}$ and $\mathrm{C}$ was obtained by using the same primer and electrophoresed on the same gel. The extended products A-D and their positions relative to the initiator ATG codon are indicated.

corresponded to the sites at $-388,-389,-390$, and -406 , respectively, relative to the initiator methionine codon (Fig. 2).

The significance of the presence of some transcription factor binding motifs in the putative promoter region are discussed as follows. The transcription factor E2F plays an important role in regulating genes involved in cell cycle control. E2F binding sites are found in the promoter region of human $c d c 2$ gene [31], human cyclin Dl gene [32], and human cyclin $A$ gene [33]. In this study, we demonstrated that $\mathrm{E} 2 \mathrm{~F}$ binding sites are present in the $5^{\prime}$ flanking region of the carp $M K K I$ gene. The involvement of E2F regulatory elements in regulating carp $M K K 1$ promoter activity is currently being investigated.

GATA-1 is an abundant protein in cells of the erythroid lineage and its binding sites are found in the promoters of many hematopoietic-specific genes [30]. Recent evidence reveals that GATA-1 can activate transcription in a synergistic manner with Sp1. In addition, the spacing of GATA-1 and Spl elements markedly influences synergistic activation of transcription. When both binding sites are well separated (about $300 \mathrm{bp}$ ) and GATA-1 and Sp1 are coexpressed, maximal transcription is achieved [34]. It is interesting to notice that there are also two potential binding sites for GATA-1 and Sp1 (separated about $250 \mathrm{bp}$ ) in the $5^{\prime}$ upstream region of the carp $M K K 1$ gene. Further investigation is required to test whether such a superactivation of GATA-1 with Sp1 may occur in the fish cell line.

The Ets superfamily is a structural class of trans-acting phosphoproteins which have important roles in the control 
of growth and development [26]. c-Ets-1 has a consensus MAP kinase phosphorylation site (PLL ${ }^{82} \mathrm{TP}$ ) and its transcriptional activity might be modulated by the Ras /MAPK pathway [35]. In fact, the activation of MKK/MEK leads to dual phosphorylation of MAP kinase and this activated MAP kinase in turn may modulate the activity of Ets-1. At present, the significance of potential Ets-1 binding site in the carp $M K K l$ gene transcription needs further investigation.

In conclusion, we have isolated and characterized the carp $M K K l$ gene. This gene is composed of 11 exons and 10 introns spanning about $9 \mathrm{~kb}$. In addition, the putative promoter region of the carp $M K K 1$ gene has several potential binding sites for transcription factors which are implicated in the control of cell cycle and proliferation. To our knowledge, this is the first report to characterize the genomic structure of the $M K K / M E K$ gene.

This research was supported by grants from the $\mathrm{Na}$ tional Science Council and from the Health Administration, Taiwan, Republic of China.

\section{References}

[1] Sturgill, T.W. and Wu, J. (1991) Biochim. Biophys. Acta 1092, 350-357.

[2] Pelech, S.L. and Sanghera, J.S. (1992) Trends Biochem. Sci. 17, 233-238.

[3] Davis, R.J. (1994) Trends Biochem. Sci. 19, 470-473.

[4] Marshall, C.J. (1995) Cell 80, 179-185.

[5] Boulton, T.G., Nye, S.H., Robbins, D.J., Ip, Y.N., Radziejewska, E., Morgenbesser, S., Depinho, R., Panayotatos, N., Cobb, M.H. and Yancopoulos, G.D. (1991) Cell 65, 663-675.

[6] Sturgill, T.W. and Ray, L.B. (1986) Biochem. Biophys. Res. Commun. 134, 565-571.

[7] Derijard, B., Hibi, M., Wu, I.-H., Barrett, T., Su, B., Deng, T., Karin, M. and Davis, R.J. (1994) Cell 76, 1025-1037.

[8] Kyriakis, J.M., Banerjee, P., Nikolakaki, E., Dai, T., Rubie, E.A., Ahmad, M.F., Avruch, J. and Woodgett, J.R. (1994) Nature 369, 156-160.

[9] Galcheva-Gargova, Z., Derijard, B., Wu, I.-H. and Davis, R.J. (1994) Science 265, 806-808.

[10] Han, J., Lee, J.-D., Bibbs, L. and Ulevitch, R.J. (1994) Science 265, 808-811.
[11] Rouse, J., Cohen, P., Trigon, S., Morange, M., Alonso-Llamazares, A., Zamanillo, D., Hunt, T. and Nebreda, A.R. (1994) Cell 78, $1027-1037$.

[12] Zhou, G., Bao, Z.Q. and Dixon, J.E. (1995) J. Biol. Chem. 270, $12665-12669$.

[13] Seger, R. and Krebs, E.G. (1995) FASEB J. 9, 726-735.

[14] Nakielny, S., Cohen, P., Wu, J. and Sturgill, T.W. (1992) EMBO J. 11, 2123-2129.

[15] Matsuda, S., Kosako, H., Takenaka, K., Moriyama, K., Sakai, H., Akiyama, T., Gotoh, Y. and Nishida, E. (1992) EMBO J. 11, 973-982.

[16] Lange-Carter, C.A., Pleiman, C.M., Gardner, A.M., Blumer, K.J. and Johnson, G.L. (1993) Science 260, 315-319.

[17] Sanchez, I., Hughes, R.T., Mayer, B.J., Yee, K., Woodgett, J.R., Avruch, J., Kyriakis, J.M. and Zon, L.I. (1994) Nature 372, 794-798.

[18] Derijard, B., Raingeaud, J., Barrett, T., Wu, I.-H., Han, J., Ulevitch, R.J. and Davis, R.J. (1995) Science 267, 682-685.

[19] Lee, J.C., Laydon, J.T., McDonnell, P.C., Gallagher, T.F., Kumar, S., Green, D., McNulty, D., Blumenthal, M.J., Heys, J.R., Landvatter, S.W., Strickler, J.E., McLaughlin, M.M., Siemens, I.R., Fisher, S.M., Livi, G.P., White, J.R., Adams, J.L. and Young, P.R. (1994) Nature 372, 739-746.

[20] Huang, C.J., Lee, M.S., Chang, G.D., Huang, F.L. and Lo, T.B. (1994) Biochim. Biophys. Acta 1220. 223-225.

[21] Breathnach, R. and Chambon, P. (1981) Annu. Rev. Biochem. 50, 349-383.

[22] McKnight, S.L. and Kingsbury, R. (1982) Science 217, 321-324.

[23] Mudryj, M., Hiebert, S.W. and Nevins, J.R. (1990) EMBO J. 9, 2179-2184.

[24] Akira, S., Isshiki, H., Sugita, T., Tanabe, O., Kinoshita, S., Nishio, Y., Nakajima, T., Hirano, T. and Kishimoto, T. (1990) EMBO J. 9, 1897-1906.

[25] Akira, S., Nishio, M., Wanf, X., Wei, S., Matsusaka, T., Yoshida, K., Sudo, T., Naruto, M. and Kishimoto, T. (1994) Cell 77, 63-71.

[26] Wasylyk, B., Hahn, S.L. and Giovane, A. (1993) Eur. J. Biochem. $211,7-18$.

[27] Faisst, S. and Meyer, S. (1992) Nucleic Acids Res. 20, 3-26.

[28] Grilli, M., Chiu, J.J.S. and Lenardo, M.J. (1993) Int. Rev. Cytol. $143,1-62$.

[29] Jackson, S.P., MacDonald, J.J., Lees-Miller, S. and Tjian, R. (1990) Cell 63, 155-165.

[30] Orkin, S.H. (1992) Blood 80, 575-581.

[31] Dalton, S. (1992) EMBL J. 11, 1797-1804.

[32] Motokura, T. and Arnold, A. (1993) Genes Chromosomes Cancer 7. 89-95.

[33] Henglein, B., Chenivesse, X., Wang, J., Eick, D. and Brechot, C. (1994) Proc. Natl. Acad. Sci. USA 91, 5490-5494.

[34] Merika, M. and Orkin, S.H. (1995) Mol. Cell. Biol. 15, 2437-2447.

[35] Brunner, D., Ducker, K., Oellers, N., Hafen, E., Scholz, H. and Klambt, C. (1994) Nature 370, 386-389. 